\title{
REVIEW OF BEARING CAPACITY AND SETTLEMENT OF PILE FOUNDATION IN PORT INFRASTRUCTURE
}

\author{
Adi Sunarno ${ }^{1}$ \\ Rinda Karlinasari², \\ Abdul Rochim ${ }^{3}$

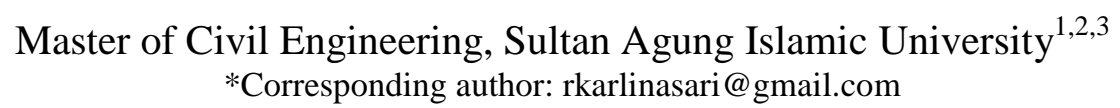

\begin{abstract}
The rapid infrastructure development is one of the indicators on the country economic progress. Indonesia as one of the largest archipelagic countries in the world, should be prioritized the port infrastructure to support the maritime. One of the government's solutions is infrastructure development of Kuala Tanjung port. This research analyzed bearing capacity and settlement of single and group pile foundation on port infrastructure of Kuala Tanjung so it is known that the port is safe to use. The data used are Standard Penetration Test data with soil stratigraphy that is clay and sand. The type of foundation used is Concrete Spun Pile $\emptyset 1000 \mathrm{~mm}$ and $\emptyset 600 \mathrm{~mm}$ with a pile length of 36 meters. The data are then analyzed by manual calculation and Allpile 6.5E program based on Reese method and methods such as Vesic and Converse-Labarre. The results showed that single pile foundations of $\emptyset 1000 \mathrm{~mm}$ and $\emptyset 600 \mathrm{~mm}$ each had allowable capacity $\left(Q_{\text {all }}\right)$ 492.78-538.81 ton and 110.65-128.31 ton, with vertical load $(Q)$ of 330.90 ton, settlement 0.56-1.17 $\mathrm{cm}$ and 3.32-3.64 cm, lateral deflection $27.50 \mathrm{~cm}$ and $94.90 \mathrm{~cm}$. While the $\emptyset 1000 \mathrm{~mm}$ and $\emptyset 600 \mathrm{~mm}$ pile group foundations respectively have $Q_{\text {all }} 8717.31-10796.29$ tons and 2059.25-2566.32 tons, with $Q$ of 6618 tons, settlement $0.56-1.68 \mathrm{~cm}$ and $3.32-3.64 \mathrm{~cm}$, lateral deflection of $2.49 \mathrm{~cm}$ and $19.49 \mathrm{~cm}$. The conclusion of the research indicates that the safe pile foundation used is $\emptyset 1000 \mathrm{~mm}$ group pile foundation.
\end{abstract}

Keywords: Bearing Capacity; Foundations; Pile Foundation; Port Infrastructure; Settlement

\section{Introduction}

The foundation is one part of the building constructions that becomes the liaison between the upper and the basic building, has a very important function that is to hold the loads of buildings on it before channeling it on the bottom ground under it. In order to maintain the stability of building construction, it is necessary to consider the bearing capacity and the settlement in the foundation. The foundation must be able to support the loads working on it in both the axial and the lateral directions without excessive settlement.

The bearing capacity and settlement in the foundation is not something new in civil engineering. Even many researchers do research on the bearing capacity and settlement in the foundation (Chairullah, 2013; Elfaaz and Hamdhan, 2016; Sihotang, 2009). In this study, the research aim is to analyze the bearing capacity (axial and lateral) and settlement on pile foundation both single pile and group pile to complete what has been studied by previous researchers.

\section{Bearing Capacity of Pile Foundation}

\subsection{Axial Bearing Capacity of Single Pile Foundation}

The axial bearing capacity of the pile foundation consists of two parts, namely skin friction capacity and end bearing capacity. Axial bearing capacity based on Reese \& Wright 
method (Lastiasih et al, 2013) is calculated based on soil type. The soil type is devided into two, namely cohesive soil and granular soil. End bearing capacity can be calculated using the Eq. (2.1):

$\mathrm{Q}_{\text {tip }}=\mathrm{A}_{\mathrm{p}} \times \mathrm{q}_{\mathrm{p}}$

Where:

$\mathrm{Q}_{\text {tip }} \quad=$ End bearing capacity

$\mathrm{A}_{\mathrm{p}} \quad=$ Sectional area of the pile

$\mathrm{q}_{\mathrm{p}} \quad=$ End resistance per unit area

To obtain $\mathrm{q}_{\mathrm{p}}$ value on cohesive soil can be used Eq. (2.2):

$\mathrm{q}_{\mathrm{p}}=9 \times \frac{2}{3} \times \mathrm{N}-\mathrm{SPT}$

The value of $\mathrm{q}_{\mathrm{p}}$ on granular soil can be used correlation between $\mathrm{q}_{\mathrm{p}}$ and N-SPT in Fig 1:

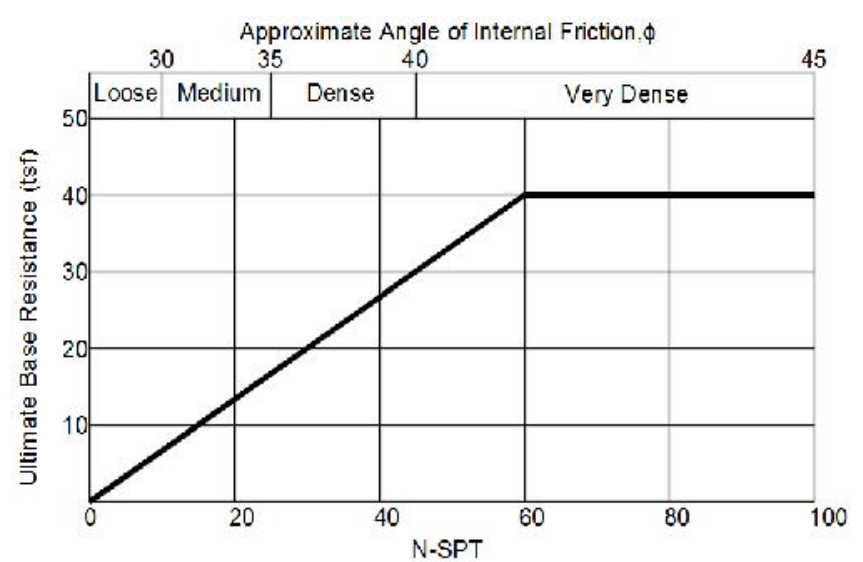

Fig. 1. Correlation $\mathrm{q}_{\mathrm{p}}$ and N-SPT Reese \& Wright

Skin friction capacity can be calculated using Eq. (2.3):

$\mathrm{Q}_{\text {skin }}=\mathrm{f} \times \mathrm{L}_{\mathrm{i}} \times \mathrm{p}$

Where:

$\mathrm{f}=$ Skin friction unit resistance

$\mathrm{L}_{\mathrm{i}} \quad=$ Layer of soil

$\mathrm{p} \quad=$ Perimeter of pile

$\mathrm{Q}_{\text {skin }}=$ Skin friction capacity

In cohesive soil, $\mathrm{f}$ can be obtained by using Eq. (2.4):

$\mathrm{f}=\alpha \times \frac{2}{3} \times \mathrm{N}-\mathrm{SPT}$

Where:

$\alpha=$ Adhesion factor (Reese $\&$ Wright $\alpha=0,55$ )

In granular soil, $f$ can be used correlation between $f$ and N-SPT in Fig 2: 


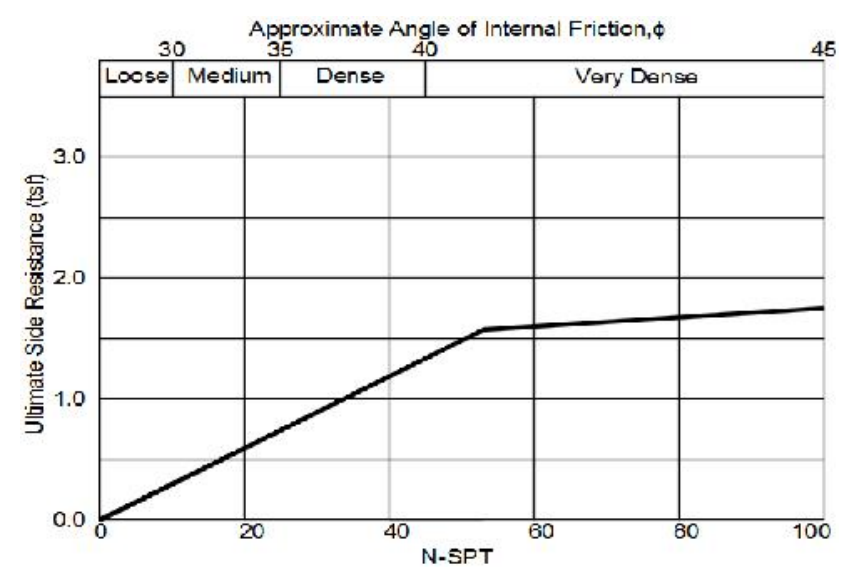

Fig. 2. Correlation $f$ and SPT Reese \& Wright

The ultimate capacity $\left(\mathrm{Q}_{\text {ult }}\right)$ can be calculated using the Eq. (2.5):

$\mathrm{Q}_{\mathrm{ult}}=\mathrm{Q}_{\mathrm{tip}}+\mathrm{Q}_{\text {skin }}$

Where:

Qult = Ultimate capacity

Allowable capacity $\left(\mathrm{Q}_{\text {all }}\right)$ of pile foundation can be calculated using Eq. (2.6):

$\mathrm{Q}_{\text {all }}=\frac{\mathrm{Q}_{\mathrm{ult}}}{\mathrm{FS}}$

Where:

Qall $\quad=$ Allowable capacity

FS $\quad=$ Factor of safety

\subsection{Axial Bearing Capacity of Group Pile Foundation}

The foundation of the group pile is the foundation used when a single pile foundation does not have sufficient capacity to withstand the existing load. Bearing capacity of group pile can be calculated using Eq. (2.7):

$\mathrm{Qg}=\mathrm{Q}_{\mathrm{all}} \times \mathrm{n} \times \mathrm{E}_{\mathrm{g}}$

Where:

$\mathrm{Q}_{\mathrm{g}} \quad=$ Bearing capacity of group pile

$\mathrm{Q}_{\text {all }} \quad=$ Allowable capacity

$\mathrm{n} \quad=$ Number of pile

The foundation capacity of the group pile in holding the load is strongly influenced by the efficiency factor. To find efficiency factor in group pile can be used Converse-Labarre (Bowles, 1996) in Eq. (2.8):

$$
E_{g}=1-0\left[\frac{(n-1) m+(m-1) n}{90 m m}\right]
$$

Where:

$\mathrm{E}_{\mathrm{g}} \quad=$ Pile group efficiency factor

$\theta \quad=\tan ^{-1} \mathrm{D} / \mathrm{s}$ 


$$
\begin{array}{ll}
\mathrm{n} & =\text { Number of pile in a row } \\
\mathrm{m} & =\text { Number of rows in a group pile } \\
\mathrm{D} & =\text { Diameter of pile } \\
\mathrm{S} & \quad=\text { Spacing between pile }
\end{array}
$$

\subsection{Lateral Bearing Capacity of Pile Foundation}

The lateral loads of the pile foundation are the loads that are in the horizontal direction. In this analysis, the head pile condition is differentiated by free head and fixed head.

\subsubsection{Free Head}

In general the behavior of pile can be expressed using Eq. (2.9):

$$
\frac{\mathrm{d}^{4} \mathrm{y}}{\mathrm{dx}^{4}}+\frac{\mathrm{k}_{\mathrm{h}} \times \mathrm{y}}{\mathrm{E}_{\mathrm{p}} \times \mathrm{I}_{\mathrm{p}}}=0
$$

The general solution of the equation can be expressed using Eq. (2.10):

$\mathrm{y}=\mathrm{f}\left(\mathrm{x}, \mathrm{T}, \mathrm{L}, \mathrm{K}_{\mathrm{h}}, \mathrm{E}_{\mathrm{p}}, \mathrm{I}_{\mathrm{p}}, \mathrm{H}, \mathrm{M}\right)$

The behavior of the pile foundation caused by lateral loads $(\mathrm{H})$ and moment $(\mathrm{M})$ that worked on the head pile in such as deflection $\left(\mathrm{y}_{\mathrm{x}}\right)$, moment $\left(\mathrm{M}_{\mathrm{x}}\right)$, angular or slope rotation $\left(\mathrm{S}_{\mathrm{x}}\right)$, shear force $\left(\mathrm{V}_{\mathrm{x}}\right)$, and soil reaction $\left(\mathrm{P}_{\mathrm{x}}\right)$.

Deflection $\left(\mathrm{y}_{\mathrm{x}}\right)$ can be calculated using Eq. (2.11):

$Y_{x}=Y_{A}+Y_{B}=A_{y} \frac{H \cdot T^{3}}{E_{p} I_{p}}+B_{y} \frac{M \cdot T^{3}}{E_{p} I_{p}}$

Moment $\left(\mathrm{M}_{\mathrm{x}}\right)$ can be calculated using Eq. (2.12):

$M x=M_{A}+M_{B}=A_{m} \cdot H \cdot T+B_{m} \cdot M$

Angular or slope rotation $\left(S_{\mathrm{x}}\right)$ can be calculated using Eq. (2.13):

$S_{\mathrm{x}}=\mathrm{S}_{\mathrm{A}}+\mathrm{S}_{\mathrm{B}}=\mathrm{A}_{\mathrm{s}} \cdot \frac{\mathrm{H} \cdot \mathrm{T}^{2}}{\mathrm{E}_{\mathrm{p}} \mathrm{I}_{\mathrm{p}}}+\mathrm{B}_{\mathrm{s}} \frac{\mathrm{M} \cdot \mathrm{T}}{\mathrm{E}_{\mathrm{p}} \mathrm{I}_{\mathrm{p}}}$

Shear force $\left(\mathrm{V}_{\mathrm{x}}\right)$ can be calculated using Eq. (2.14):

$\mathrm{V}_{\mathrm{x}}=V_{A}+V_{B}=A_{V} \cdot H+B_{V} \frac{M}{T}$

Soil reaction $\left(\mathrm{P}_{\mathrm{x}}\right)$ can be calculated using Eq. (2.15):

$\mathrm{P}_{\mathrm{x}}=\mathrm{P}_{\mathrm{A}}+\mathrm{P}_{\mathrm{B}}=\mathrm{A}_{\mathrm{p}} \frac{\mathrm{H}}{\mathrm{T}}+\mathrm{B}_{\mathrm{p}} \frac{\mathrm{M}}{\mathrm{T}^{2}}$

The values of equations such as $A_{y}, A_{s}, A_{m}, A_{p}, B_{y}, B_{s}, B_{m}, B_{v}$ and $B_{p}$ described above can be seen in Table 1 [6]:

Table 1. Coefficients A and B Free Head

\begin{tabular}{ccccccccccc}
\hline $\mathbf{Z}$ & $\mathbf{A}_{\mathbf{y}}$ & $\mathbf{A}_{\mathbf{s}}$ & $\mathbf{A}_{\mathbf{m}}$ & $\mathbf{A}_{\mathbf{v}}$ & $\mathbf{A}_{\mathbf{p}}$ & $\mathbf{B}_{\mathbf{y}}$ & $\mathbf{B}_{\mathbf{s}}$ & $\mathbf{B}_{\mathbf{m}}$ & $\mathbf{B}_{\mathbf{v}}$ & $\mathbf{B}_{\mathbf{p}}$ \\
\hline 0.0 & 2.435 & -1.623 & 0.000 & 1.000 & 0.000 & 1.623 & -1.750 & 1.000 & 0.000 & 0.000 \\
\hline 0.1 & 2.273 & -1.618 & 0.100 & 0.989 & -0.227 & 1.453 & -1.650 & 1.000 & -0.007 & -0.145 \\
\hline 0.2 & 2.112 & -1.603 & 0.198 & 0.956 & -0.442 & 1.293 & -1.550 & 0.999 & -0.028 & -0.259 \\
\hline 0.3 & 1.952 & -1.578 & 0.291 & 0.906 & -0.586 & 1.143 & -1.450 & 0.994 & -0.058 & -0.343 \\
\hline 0.4 & 1.796 & -1.545 & 0.379 & 0.840 & -0.718 & 1.003 & -1.351 & 0.987 & -0.095 & -0.401 \\
\hline 0.5 & 1.644 & -1.503 & 0.459 & 0.764 & -0.822 & 0.873 & -1.253 & 0.976 & -0.137 & -0.436 \\
\hline
\end{tabular}




\begin{tabular}{ccccccccccc}
\hline $\mathbf{Z}$ & $\mathbf{A}_{\mathbf{v}}$ & $\mathbf{A}_{\mathbf{s}}$ & $\mathbf{A}_{\mathbf{m}}$ & $\mathbf{A}_{\mathbf{v}}$ & $\mathbf{A}_{\mathbf{p}}$ & $\mathbf{B}_{\mathbf{v}}$ & $\mathbf{B}_{\mathbf{s}}$ & $\mathbf{B}_{\mathbf{m}}$ & $\mathbf{B}_{\mathbf{v}}$ & $\mathbf{B}_{\mathbf{p}}$ \\
\hline 0.6 & 1.496 & -1.454 & 0.532 & 0.677 & -0.897 & 0.752 & -1.156 & 0.960 & -0.181 & -0.451 \\
\hline 0.7 & 1.353 & -1.397 & 0.595 & 0.585 & -0.947 & 0.642 & -1.061 & 0.939 & -0.226 & -0.449 \\
\hline 0.8 & 1.216 & -1.335 & 0.649 & 0.489 & -0.973 & 0.540 & -0.968 & 0.914 & -0.270 & -0.432 \\
\hline 0.9 & 1.086 & -1.268 & 0.693 & 0.392 & -0.977 & 0.448 & -0.878 & 0.885 & -0.312 & -0.403 \\
\hline 1.0 & 0.962 & -1.197 & 0.727 & 0.295 & -0.962 & 0.364 & -0.792 & 0.852 & -0.350 & 0.364 \\
\hline 1.2 & 0.738 & -1.047 & 0.767 & 0.109 & -0.885 & 0.223 & -0.629 & 0.775 & -0.414 & -0.268 \\
\hline 1.4 & 0.544 & -0.893 & 0.772 & -0.056 & -0.761 & 0.112 & -0.482 & 0.688 & -0.456 & -0.157 \\
\hline 1.6 & 0.381 & -0.741 & 0.746 & -0.193 & -0.609 & 0.029 & -0.354 & 0.594 & -0.477 & -0.047 \\
\hline 1.8 & 0.247 & -0.596 & 0.696 & -0.298 & -0.445 & -0.030 & -0.245 & 0.498 & -0.476 & 0.054 \\
\hline 2.0 & 0.142 & -0.464 & 0.628 & -0.371 & -0.283 & -0.070 & -0.155 & 0.404 & -0.456 & 0.140 \\
\hline 3.0 & -0.075 & -0.040 & -0.225 & -0.349 & 0.226 & -0.089 & 0.057 & 0.059 & -0.213 & 0.268 \\
\hline 4.0 & -0.050 & 0.052 & 0.000 & -0.106 & 0.201 & -0.028 & 0.049 & -0.042 & 0.017 & 0.112 \\
\hline 5.0 & -0.009 & 0.025 & -0.033 & 0.015 & 0.046 & 0.00 & -0.011 & -0.026 & 0.029 & -0.002 \\
\hline
\end{tabular}

\subsubsection{Fixed Head}

On the pile with condition fixed head rotation angle value or slope found in the pile head is equals 0 (null), so it can be written Eq. (2.16):

$$
\mathrm{S}_{\mathrm{x}}=\mathrm{S}_{\mathrm{A}}+\mathrm{S}_{\mathrm{B}}=\mathrm{A}_{\mathrm{s}} \frac{\mathrm{H} \cdot \mathrm{T}^{2}}{\mathrm{E}_{\mathrm{p}} \mathrm{I}_{\mathrm{p}}}+\mathrm{B}_{\mathrm{s}} \frac{\mathrm{M} \cdot \mathrm{T}}{\mathrm{E}_{\mathrm{p}} \mathrm{I}_{\mathrm{p}}}=0
$$

The values of $A_{s}$ and $B_{s}$ can be seen in the Table 2 which has been described previously in the free head condition. Substituting the values of $A_{s}$ and $B_{s}$ in the equation, then for $\mathrm{x}=0$ obtained Eq. (2.17):

$$
\frac{\mathrm{M}}{\mathrm{H} . \mathrm{T}}=-\frac{\mathrm{A}_{\mathrm{s}}}{\mathrm{B}_{\mathrm{s}}}=-\frac{1.623}{1.75}=-0.93
$$

So obtained the Eq. (2.18):

$\mathrm{M}=-0.93 \times \mathrm{H} \times \mathrm{T}$

Deflection $\left(\mathrm{y}_{\mathrm{f}}\right)$ can be calculated using Eq. (2.19):

$\mathrm{y}_{\mathrm{F}}=\mathrm{F}_{\mathrm{y}} \frac{\mathrm{H} \cdot \mathrm{T}^{3}}{\mathrm{E}_{\mathrm{p}} \mathrm{I}_{\mathrm{p}}}$

Moment $\left(\mathrm{M}_{\mathrm{f}}\right)$ can be calculated using Eq. (2.20):

$\mathrm{M}_{\mathrm{F}}=\mathrm{F}_{\mathrm{m}} \times \mathrm{H} \times \mathrm{T}$

Soil resistance $\left(\mathrm{P}_{\mathrm{f}}\right)$, can be calculated using Eq. (2.21):

$\mathrm{P}_{\mathrm{F}}=\mathrm{F}_{\mathrm{p}} \frac{\mathrm{H}}{\mathrm{T}}$

The values of $F_{y}, F_{m}$ and $F_{p}$ can be seen in Fig 3, Fig 4 and Fig 5 :

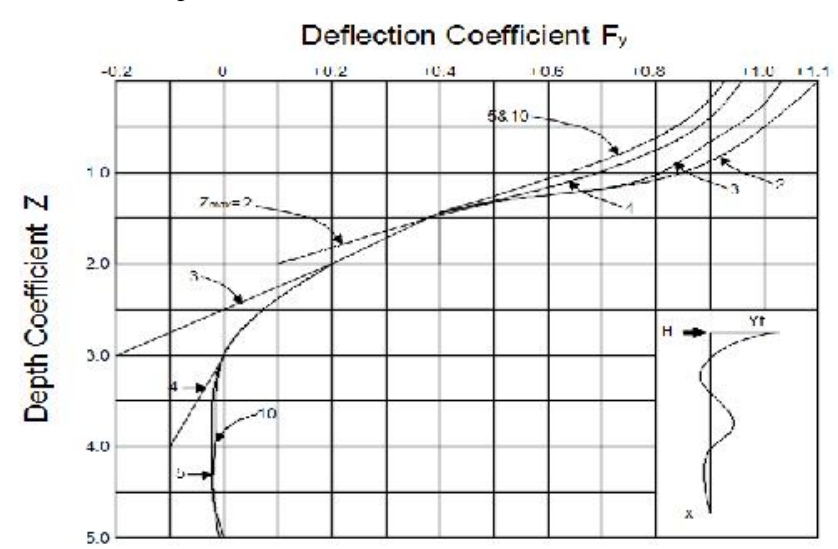

Fig. 3. Coefficients Deflection $\left(F_{y}\right)$ Fixed Head 


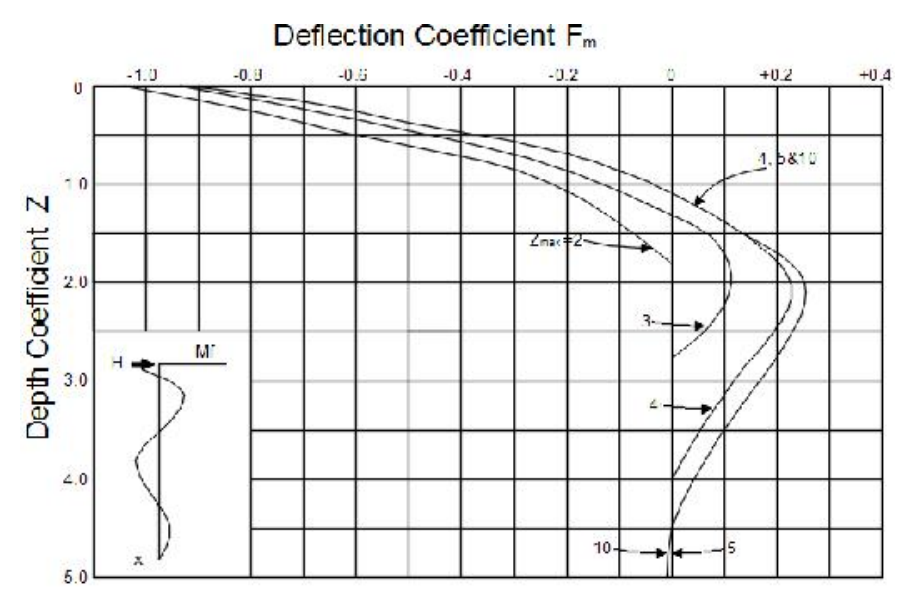

Fig. 4. Coefficients Moment $\left(\mathrm{F}_{\mathrm{m}}\right)$ Fixed Head

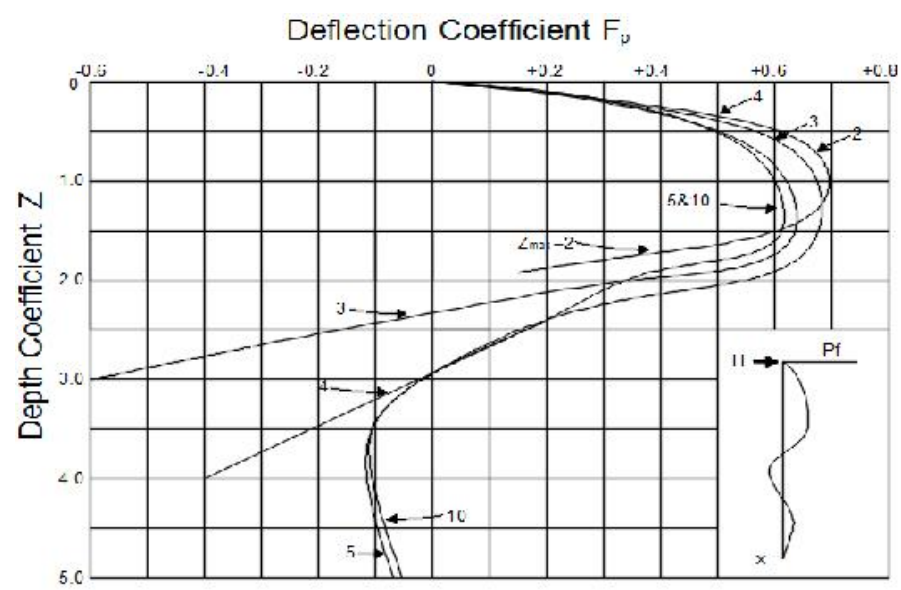

Fig. 5. Coefficients of Soil Reaction $\left(\mathrm{F}_{\mathrm{p}}\right)$ Fixed Head

\subsection{Elastic Settlement of Single Pile Foundation}

The total pile settlement under a vertical work load can be calculated using Eq. (2.22):

$\mathrm{S}_{\mathrm{e}}=S_{e(1)}+S_{e(2)}+S_{e(3)}$

Where:

$\mathrm{S}_{\mathrm{e}(1)} \quad=$ Elastic settlement of pile

$\mathrm{S}_{\mathrm{e}(2)} \quad=$ Settlement of pile caused by the load at the pile tip

$\mathrm{S}_{\mathrm{e}(3)} \quad=$ Settlement of pile caused by the load at the pile blanket

Elastic settlement of pile $\mathrm{S}_{\mathrm{e}(1)}$ can be calculated using Eq. (2.23)

$S_{e(1)}=\frac{\left(Q_{w p}+\xi Q_{w s}\right) L}{A_{p} E_{p}}$

Where:

$\mathrm{Q}_{\mathrm{wp}} \quad=$ Load carried at the pile point under working load

$\mathrm{Q}_{\mathrm{ws}} \quad=$ Load carried by frictional (skin) resistance under working load condition

$\mathrm{L}=$ = Length of pile

$\mathrm{E}_{\mathrm{p}} \quad=$ Modulus of elasticity of the pile material 
The magnitude of $\xi$ varies between 0.5 and 0.67 which depend on the distribution of skin friction resistance. Vesic [7] also proposes a semi-empirical method to derive the magnitude of $\mathrm{S}_{\mathrm{e}(2)}$ settlement can be used Eq. (2.24):

$\mathrm{S}_{\mathrm{e}(2)}=\frac{\mathrm{Q}_{\mathrm{wp}} \cdot \mathrm{C}_{\mathrm{p}}}{\mathrm{D} \cdot \mathrm{q}_{\mathrm{p}}}$

Where:

$\mathrm{q}_{\mathrm{p}}=$ Ultimate pile tip resistance

$\mathrm{C}_{\mathrm{p}}=$ Empirical coefficients

The completed $\mathrm{C}_{\mathrm{p}}$ value can be seen in Table 2 [7]:

Table 2. $\mathrm{C}_{\mathrm{p}}$ Value

\begin{tabular}{ccc}
\hline Soil Type & Driven Pile & Bored Pile \\
\hline Sand (dense to loose) & $0.02-0.04$ & $0.09-0.18$ \\
\hline Clay (stiff to soft) & $0.02-0.03$ & $0.03-0.06$ \\
\hline Silt (dense to loose) & $0.03-0.05$ & $0.09-0.12$ \\
\hline
\end{tabular}

Vesic [7] also proposes a simple empirical relation obtain $\mathrm{S}_{\mathrm{e}(3)}$ can be used Eq. (2.25):

$\mathrm{S}_{\mathrm{e}(3)}=\frac{\mathrm{Q}_{\mathrm{ws}} \cdot \mathrm{C}_{\mathrm{s}}}{\mathrm{L} \cdot \mathrm{q}_{\mathrm{p}}}$

Where:

$\mathrm{C}_{\mathrm{s}} \quad=$ Empirical constant $=\left(0.93+0.1 \sqrt{\mathrm{L} / \mathrm{D})} \mathrm{C}_{\mathrm{p}}\right.$

\subsection{Elastic Settlement of Group Pile Foundation}

The simplest relationship for the settlement of the elastic settlement of group pile (Vesic, 1969) can be calculated using Eq. (2.26):

$S_{g(e)}=\sqrt{\frac{B_{g}}{D}} S_{e}$

Where:

$\mathrm{S}_{\mathrm{g}(\mathrm{e})} \quad=$ Elastic settlement of group pile

$\mathrm{B}_{\mathrm{g}} \quad=$ Width of group pile

$\mathrm{D}=$ Diameter of pile

$\mathrm{S}=$ = Elastic settlement of single pile

\section{Data and Research Results}

\subsection{Research of Data}

The data related to infrastructure development of Kuala Tanjung Port districts of Batu Bara in North Sumatera Province, includes 4 (four) kinds of data, they were research location data, soil data foundation data and loading data.

The data of location can be seen in Fig 6: 


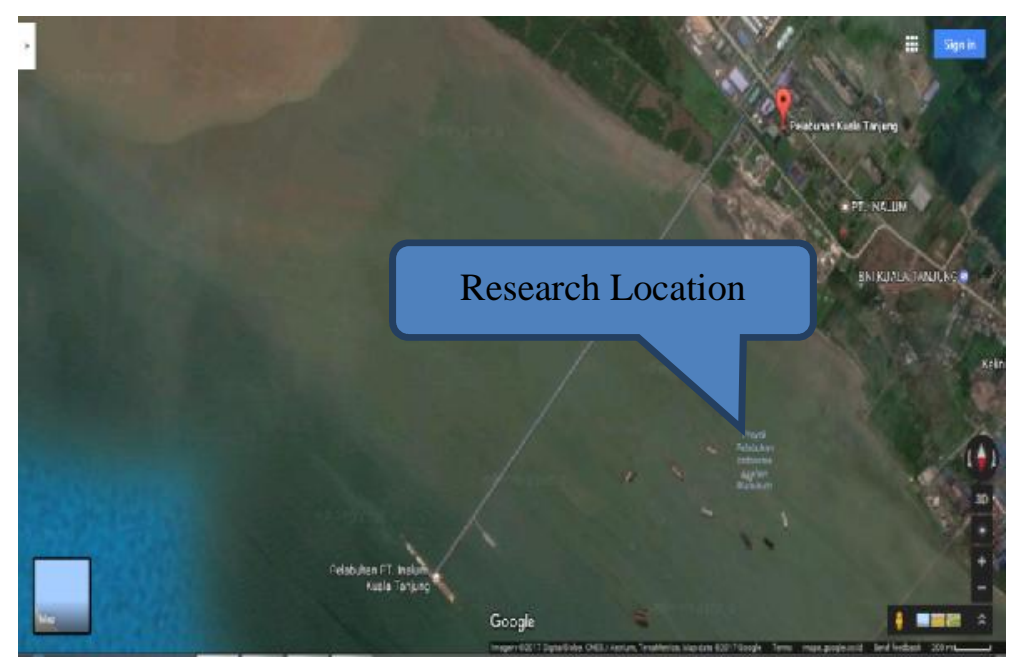

Fig. 6. Research Location

Kuala Tanjung Port is a port located in Kuala Tanjung district of Batu Bara in North Sumatera Province. Kuala Tanjung Port has a very strategic role because it is located along in Selat Malaka which is an international traude routes. The development of Kuala Tanjung Port is expected to increase the economy and welfare of the community and also to increase the competitiveness of our country with the other.

The soil data used in this research can be seen in the Table 3:

Table 3. Soil Data

\begin{tabular}{cccc}
\hline Depth $(\mathbf{m})$ & $\Delta \boldsymbol{l}(\mathbf{m})$ & Soil Type & N-SPT Average \\
\hline $0-8$ & 8 & Clay & 1.60 \\
\hline $8-13$ & 5 & Clay & 5.66 \\
\hline $13-18$ & 5 & Sand & 15.50 \\
\hline $18-24$ & 6 & Sand & 22.50 \\
\hline $24-28$ & 4 & Sand & 28.00 \\
\hline $28-34$ & 6 & Sand & 29.750 \\
\hline $34-38$ & 4 & Sand & 31.33 \\
\hline $38-41$ & 3 & Sand & 34.00 \\
\hline $41-44$ & 3 & Sand & 37.50 \\
\hline $44-50$ & 6 & Sand & 41.75 \\
\hline
\end{tabular}

Based on the Table 3, it can be concluded that type of soil in the research area were clay and sand, where clay is at a depth of 0-13 meters, whereas the sand is at a depth of 1350 meters.

Foundation data of Concrete Spun Pile can be seen in the Table 4 and Fig 7:

Table 4. Pile Data

\begin{tabular}{ccc}
\hline Parameters & Value & Unit \\
\hline \multirow{2}{*}{ Diameter } & 1000 & $\mathrm{~mm}$ \\
\hline Pile Lenght & 600 & $\mathrm{~mm}$ \\
\hline Waterfront & 36 & $\mathrm{~m}$ \\
\hline Quality of concrete (fc') & 1.89 & $\mathrm{~m}$ \\
\hline Modulus of elasticity & 49.80 & $\mathrm{MPa}$ \\
\hline
\end{tabular}




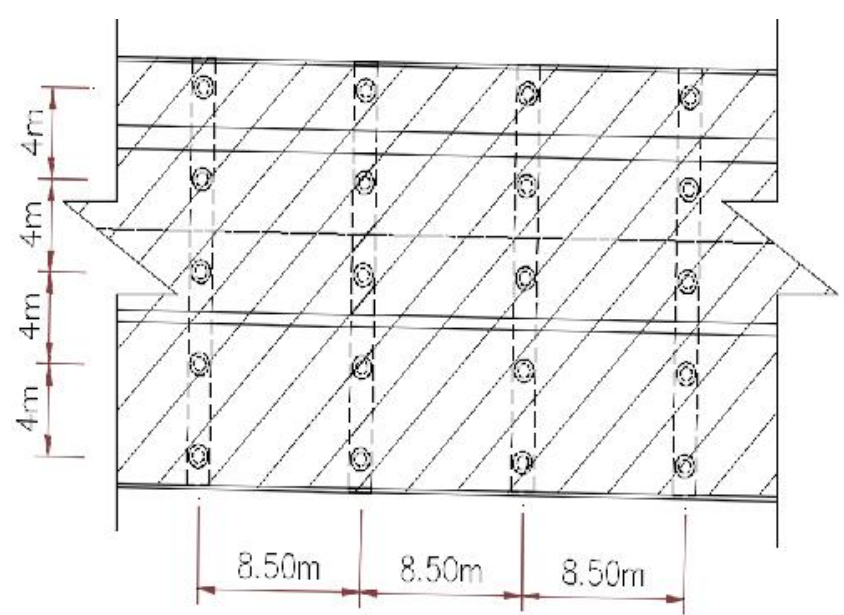

Fig. 7. Foundation Plan

Based on the Fig 7 above, it can be known that the number of pile on the row of lines is 4 lines with a distance of 8.50 meters whereas the number of pile on the row of columns is 5 columns with a distance of 4 meters.

The foundation load data of Concrete Spun Pile can be seen on the Table 5 and Table 6:

Table 5. Loads Single Pile

\begin{tabular}{lcc}
\hline \multicolumn{1}{c}{ Parameters } & Value & Unit \\
\hline Load vertical $(\mathrm{Q})$ & 3309 & $\mathrm{kN}$ \\
\hline Shear $(\mathrm{P})$ & 21.60 & $\mathrm{kN}$ \\
\hline Moment $(\mathrm{M})$ & 1069 & $\mathrm{kN}$ \\
\hline
\end{tabular}

Table 6. Loads Group Pile

\begin{tabular}{lcc}
\hline \multicolumn{1}{c}{ Parameters } & Value & Unit \\
\hline Load vertical $(\mathrm{Q})$ & 66180 & $\mathrm{kN}$ \\
\hline Shear $(\mathrm{P})$ & 432.00 & $\mathrm{kN}$ \\
\hline Moment $(\mathrm{M})$ & 21380 & $\mathrm{kN}$ \\
\hline
\end{tabular}

\section{Results}

\subsubsection{Axial Bearing Capacity and Settlement of Single Pile}

Axial bearing capacity and settlement of single pile concrete spun pile $\varnothing 1000 \mathrm{~mm}$ and $\emptyset 600 \mathrm{~mm}$ based on the manual calculation and analysis with the program of AllPile can be seen in the Table 7 and Table 8 as the following:

Table 7. The Results of Analysis Axial Single Pile $\emptyset 1000 \mathrm{~mm}$

\begin{tabular}{lccc}
\hline \multirow{2}{*}{ Description } & \multicolumn{2}{c}{ Analysis } & \multirow{2}{*}{ Unit } \\
\cline { 2 - 3 } & Manual & Program AllPile & \\
\hline Total Allowable Capacity & 492.78 & 539.81 & ton \\
\hline Settlement & 1.17 & 0.56 & $\mathrm{~cm}$ \\
\hline
\end{tabular}

Table 8. The Results of Analysis Axial Single Pile $\varnothing 600 \mathrm{~mm}$

\begin{tabular}{lccc}
\hline \multirow{2}{*}{ Description } & \multicolumn{2}{c}{ Analysis } & \multirow{2}{*}{ Unit } \\
\cline { 2 - 3 } & Manual & Program AllPile & \\
\hline Total Allowable Capacity & 110.65 & 128.31 & ton \\
\hline Settlement & 3.64 & 3.32 & $\mathrm{~cm}$ \\
\hline
\end{tabular}


Based on the Table 7 and Table 8 above, it can be known that is foundation capable of holding vertical load (Q) of 330.90 tons is the pile foundation of $\varnothing 1000 \mathrm{~mm}$ with allowable capacity between $492.78-539.81$ tons.

\subsubsection{Axial Bearing Capacity and Settlement of Group Pile}

Axial bearing capacity and settlement of group pile concrete spun pile $\varnothing 1000 \mathrm{~mm}$ and $\emptyset 600 \mathrm{~mm}$ based on the manual calculation and analysis with the program of AllPile can be seen on the Table 9 and Table 10 as the following:

Table 9. The Results of Analysis Axial Group Pile $\emptyset 1000$ mm

\begin{tabular}{lccc}
\hline \multirow{2}{*}{ Description } & \multicolumn{2}{c}{ Analysis } & \multirow{2}{*}{ Unit } \\
\cline { 2 - 3 } & Manual & Program AllPile & \\
\hline Total Allowable Capacity & 8717.31 & 10796.29 & ton \\
\hline Settlement & 1.68 & 0.56 & $\mathrm{~cm}$ \\
\hline
\end{tabular}

Table 10. The Results of Analysis Axial Group Pile $\emptyset 600 \mathrm{~mm}$

\begin{tabular}{lccc}
\hline \multirow{2}{*}{ Description } & \multicolumn{2}{c}{ Analysis } & \multirow{2}{*}{ Unit } \\
\cline { 2 - 4 } & Manual & Program AllPile & \\
\hline Total Allowable capacity & 2059.25 & 2566.32 & ton \\
\hline Settlement & 3.64 & 3.32 & $\mathrm{~cm}$ \\
\hline
\end{tabular}

Based on the Table 9 and Table 10 above, it can be known that foundation capable of holding vertical load (Q) of 6618 tons is the pile foundation of $\varnothing 1000 \mathrm{~mm}$ with allowable capacity between $8717.31-10796.29$ tons

\subsubsection{Lateral Bearing Capacity of Single Pile}

Lateral bearing capacity of single pile concrete spun pile $\varnothing 1000 \mathrm{~mm}$ and $\emptyset 600 \mathrm{~mm}$ can be seen on the Table 11 and Table 12 as the following:

Table 11. The Results of Analysis Lateral Single Pile $\emptyset 1000 \mathrm{~mm}$

\begin{tabular}{lcc}
\hline \multicolumn{1}{c}{ Analysis } & Result & Unit \\
\hline Top Deflection, yt & 27.50 & $\mathrm{~cm}$ \\
\hline Allowable Deflection & 2.50 & $\mathrm{~cm}$ \\
\hline
\end{tabular}

Table 12. The Results of Analysis Lateral Single Pile $\emptyset 600 \mathrm{~mm}$

\begin{tabular}{ccc}
\hline \multicolumn{1}{c}{ Analysis } & Result & Unit \\
\hline Top Deflection, yt & 94.90 & $\mathrm{~cm}$ \\
\hline Allowable Deflection & 2.50 & $\mathrm{~cm}$ \\
\hline
\end{tabular}

Based on the Table 11 and Table 12 above, deflection occurring on the pile foundation $\varnothing 1000 \mathrm{~mm}$ and $\varnothing 600 \mathrm{~mm}$ which is each of 27.50 tons and $94.90 \mathrm{~cm}$, exceeds the limit of allowable deflection of $2.50 \mathrm{~cm}$.

\subsubsection{Lateral Bearing Capacity of Group Pile}

Lateral bearing capacity of group pile concrete spun pile with $\emptyset 1000 \mathrm{~mm}$ and $\varnothing 600$ $\mathrm{mm}$ can be seen on the Table 13 and Table 14 as the following: 
Table 13. The Results of Analysis Lateral Group Pile $\emptyset 1000 \mathrm{~mm}$

\begin{tabular}{lcc}
\hline \multicolumn{1}{c}{ Analysis } & Result & Unit \\
\hline Lateral Cap Movement (Deflection), yt & 2.49 & $\mathrm{~cm}$ \\
\hline Allowable Deflection & 2.50 & $\mathrm{~cm}$ \\
\hline
\end{tabular}

Table 14. The Results of Analysis Lateral Group Pile $\emptyset 600 \mathrm{~mm}$

\begin{tabular}{lcc}
\hline \multicolumn{1}{c}{ Analysis } & Result & Unit \\
\hline Lateral Cap Movement (Deflection), yt & 19.49 & $\mathrm{~cm}$ \\
\hline Allowable Deflection & 2.50 & $\mathrm{~cm}$ \\
\hline
\end{tabular}

Based on the Table 13 and Table 14 above, deflection occuring on the pile foundation of $\emptyset 1000 \mathrm{~mm}$ and of $\varnothing 600 \mathrm{~mm}$ which is each of 2.49 and $94.90 \mathrm{~cm}$. On the foundation of $\emptyset 1000 \mathrm{~mm}$ deflection occuring suffice allowable deflection, whereas on the foundation of $\emptyset 600 \mathrm{~mm}$ deflection occuring exceeds of allowable deflection $2.50 \mathrm{~cm}$.

\section{Conclution and Recommendation}

\subsection{Conclusion}

Based on the result of manual calculation and analysis used the program of AllPile with version $6.5 \mathrm{E}$ it can be councluded that was safe pile foundation used in infrastructure development of Kuala Tanjung Port was Settlement of Group Pile of $\emptyset 1000 \mathrm{~mm}$. That was because of the foundation of $\varnothing 1000 \mathrm{~mm}$ has axial bearing capacity between 8717.3110796.29 tons which can be able to hold the vertical load of 6618 tons, with settlement of 0.56-1.68 and deflection occuring of 2.49 not exceeding the allowable deflection. Whereas the foundation of single pile of $\varnothing 600 \mathrm{~mm}$ no safe to used. On the foundation of single pile of $\varnothing 1000 \mathrm{~mm}$ axial bearing capacity between $492.78-539.81$ tons be able to hold the vertical load of 330.90 tons with settlement of $0.56-1.17 \mathrm{~cm}$ but the deflection is occured of $27.50 \mathrm{~cm}$ exceeding the allowable deflection of $2.50 \mathrm{~cm}$. On the foundation single pile of $\emptyset 600 \mathrm{~mm}$ axial bearing capacity between $110.67-128.31$ tons not be able to hold the vertical load of 330.90 tons with settlement 3.32-3.64 cm and deflection which is occured of $94.50 \mathrm{~cm}$ exceeding the allowable deflection of $2.50 \mathrm{~cm}$. Whereas on the foundation of pile group of $\varnothing 600 \mathrm{~mm}$ axial bearing capacity between of 2059.25-2566.32 tons not be able to support the vertical load of 6618 tons with settlement 3.32-3.64 cm and deflection which is occured of $19.49 \mathrm{~cm}$ exceeding the allowable deflection of $2.50 \mathrm{~cm}$.

\subsection{Recommendation}

Need to be considered and comparing used pile foundation concrete Spun Pile with the other as both in terms of culture, quality and time. 


\section{Acknowledgements}

Alhamdulillah, all praises be to Allah that has given all the pleasures. With the gifts and conveniences that Allah gave, so researchers can be completed this research. Thanks to master in Civil Engineering, Faculty of Engineering Sultan Agung Islamic University Semarang and all parties for the participation and support.

\section{References}

Bowles, J. E. (1996). Foundation and Analysis and Design, McGraw-Hill, New York.

Chairullah, B. (2013). Analisa Daya Dukung Pondasi dengan Metoda SPT, CPT, dan Meyerhof pada Lokasi Rencana Konstruksi PLTU Nagan Raya Provinsi Aceh. Teras Jurnal, Vol. 3, No. 1, 15-24.

Elfaaz, F. M., \& Hamdhan, I. N. (2016). Analisis Daya Dukung Lateral Fondasi Tiang Tunggal Menggunakan Metode Elemen Hingga. Jurnal Online Institut Teknologi Nasional, Vol. 2 No. 3, 1-12.

Lastiasih, Y., Irsyam, M., Sidi, I. D., \& Toha, F. (2013). Reabilitas Daya Dukung Pondasi Tiang Bor Berdasarkan Formula Reese \& Wright dan Usulan Load Resistance Factor Design dalam Perencanaan Pondasi Tiang Bor Studi Kasus Proyek Jakarta. Jurnal Media Komunikasi Teknik Sipil, 135-140.

Sihotang, I. E. (2009). Analisis Daya Dukung Tiang Pancang Pada Proyek Pembangunan Gedung Kanwil DJP dan KPP Sumbagut I Jalan Suka Mulia Medan. Tugas Akhir Fakultas Teknik Universitas Sumatera Utara.

Universitas Katolik Parahyangan (2013). Manual Pondasi Tiang Edisi 4. Bandung: Universitas Katolik Parahyangan.

Vesic, A. S. (1969). Experiments With Instrumented Pile Groups in Sand, American Society For Testing and Materials, Special Technical Publication No. 444, pp. 177222.

Vesic, A. S. (1997). Design of Pile Foundations, National Coorporate Highway Research Program Synthesis of Practice No. 42, Transportation Research Board, Washington, DC. 